quaternary ammonium compound, which was readily available in this hospital and which does not damage or discolor furniture, carpets, or equipment. It remains possible that briefer application of stronger disinfectants, such as phenolics or dilute hypochlorite solutions, could be more costeffective. Data are needed regarding the efficacy and costeffectiveness of such alternatives.

96-CC-171. Address reprint requests to Barry Farr, $M D, M S c$, University of Virginia Health Sciences Center, Box 473, Charlottesville, VA 22908.

\section{REFERENCES}

1. Schaberg DR, Culver DH, Gaynes RP. Major trends in the microbial etiology of nosocomial infection. Am J Med 1991;91(suppl 3B):72S-75S.

2. Emori TG, Gaynes RP. An overview of nosocomial infections, including the role of the microbiology laboratory. Clin Microbiol Rev 1993;6(4):428-442.

3. Centers for Disease Control and Prevention. Nosocomial enterococci resistant to vancomycin-United States, 1989-1993. MMWR 1993;42(30):597-599.

4. Boyle JF, Soumakis SA, Rendo A, Herrington JA, Gianarkis DG, Thurberg BE, et al. Epidemiologic analysis and genotypic characterization of a nosocomial outbreak of vancomycin-resistant enterococci. J Clin Microbiol 1993;31(5):1280-1285.

5. Frieden TR, Munsiff SS, Low DE, Willey BM, Williams G, Faur $\mathrm{Y}$, et al. Emergence of vancomycin-resistant enterococci in New York City. Lancet 1993;342:76-79.

6. Edmond MB, Ober JF, Weinbaum DL, Pfaller MA, Hwang T, Sanford MD, et al. Vancomycin-resistant Enterococcus faecuim bacteremia: risk factors for infection. Clin Infect Dis 1995;20:1126-1133.

7. Anderson RL, Carr JH, Bond WW, Favero MS. Susceptibility of vancomycin-resistant enterococci to environmental disinfectants. Infect Control Hosp Epidemiol 1997;18:195-199.

8. Rutala WA, Stiegel MM, Sarubbi FA, Weber DJ. Susceptibility of antibiotic-susceptible and antibiotic-resistant hospital bacteria to disinfectants. Infect Control Hosp Epidemiol 1997;18:417-421.

9. Morris JG Jr, Shay DK, Hebden JN, McCarter RJ Jr, Perdue BE, Jarvis W, et al. Enterococci resistant to multiple antimicrobial agents, including vancomycin. Establishment of endemicity in a university medical center. Ann Intern Med 1995;123:250-259.
10. Slaughter S, Hayden M, Nathan C, Hu TC, Rice T, Van Voorhis $\mathrm{J}$, et al. A comparison of the effect of universal use of gowns with that of glove use alone on acquisition of vancomycin-resistant enterococci in a medical ICU. Ann Intern Med 1996;125:448-456.

11. Karanfil LV, Murphy M, Josephson A, Gaynes R, Mandel L, Hill $\mathrm{BC}$, et al. A cluster of vancomycin-resistant Enterococcus faecium in an intensive care unit. Infect Control Hosp Epidemiol 1992;13:195-200.

12. Boyce JM, Opal SM, Chow JW, Zervos MJ, Potter-Bynoe G, Sherman $\mathrm{CB}$, et al. Outbreak of multidrug-resistant Enterococcus faecium with transferable van B class vancomycin resistance. J Clin Microbiol 1994;32(5):1148-1153.

13. Shay DK, Maloney SA, Montecalvo M, Banerjee S, Wormser GP, Arduino MJ, et al. Epidemiology and mortality risk of vancomycin-resistant enterococcal bloodstream infections. J Infect Dis 1995;172:993-1000.

14. Livornese LL Jr, Dias S, Samel C, Romanowski B, Taylor S, May P, et al. Hospital-acquired infection with vancomycin-resistant Enterococcus faecium transmitted by electronic thermometers. Ann Intern Med 1992;117(2):112-116.

15. Hebden J, Shay D, Schwalbe R, Standiford H, Morris G, Jarvis W. Outbreak of vancomycin-resistant Enterococcus faecium (VRE) infection/colonization among pediatric patients. Presented at the 34th Interscience Conference on Antimicrobial Agents and Chemotherapy; October 1994; Orlando, FL. Abstract J251.

16. Lacey S, Ward L, Rogers T, Morrison D, Woodford N, Johnson A. Investigation of an outbreak of vancomycin resistant Enterococcus faecium. Presented at the 34th Interscience Conference on Antimicrobial Agents and Chemotherapy; October 1994; Orlando, FL. Abstract J253.

17. Falk PS, Winnike J, Woodmansee C, et al. Outbreak due to vancomycin-resistant enterococci (VRE) in a burn intensive care unit (BICU). Presented at the seventh Annual Meeting of the Society for Healthcare Epidemiology of America; April, 1997; St. Louis, MO. Abstract 50.

18. Saurina G, Landman D, Quale JM. Activity of disinfectants against vancomycin-resistant Enterococcus faecium. Infect Control Hosp Epidemiol 1997;18:345-347.

19. Schmidt EA. SaniMaster III vs. Vancomycin-Resistant Enterococci. Downers Grove, IL: The ServiceMaster Company; February 18, 1993. Technical Development Department. Bulletin 94TB3822.

\title{
CDC's Epidemic Intelligence Service Portrayed in New Book
}

Gina Pugliese, RN, MS

Martin S. Favero, PhD

The usual portrayal of epidemic investigations by CDC's Epidemic Intelligence Service (EIS) Officers in novels or movies is laced with hyperbole and quite often does not pass the laugh test with those who are familiar with the EIS or have worked at the CDC. In his new novel The Cobra Event, Richard Preston, author of The Hot Zone, describes an outbreak of disease in New York City that is linked to the development and deployment of a modern biological weapon. In describing the outbreak and the subsequent involvement of the CDC, its response, and a fictional EIS Officer's investigation, Preston has written a most accurate and credible account of the CDC's operations in crisis. It is clear that he spent a good deal of time in Atlanta observing the world of the CDC and interviewing epidemiologists and scientists about epidemic investigations and mechanisms of genetic alteration of pathogens and transmission of pathogens. Building 6 at the CDC becomes as real as a photograph with its champagne-in-a-tin-cup image, as does the gleaming vision of Building 15 , the maximum containment facility designed to contain highly dangerous microbial pathogens. The story is interesting and for the most part credible. For the infection control community, the book is a must read.

FROM: Preston R. The Cobra Event. New York City, NY: Random House; 1997. 